\title{
PERAN BRAND IMAGEMEMEDIASI HUBUNGAN KREDIBILITAS CELEBRITY ENDORSER DENGAN NIAT BELI
}

\author{
Cokorda Istri Gita Apsari Dewi ${ }^{1}$ \\ I Ketut Rahyuda ${ }^{2}$ \\ ${ }^{1,2}$ Fakultas Ekonomi dan Bisnis Universitas Udayana (Unud), Bali, Indonesia \\ email: cokgita28@gmail.com
}

\begin{abstract}
ABSTRAK
Penelitian ini bertujuan untuk menguji pengaruh kredibilitas celebrity endorser terhadap niat beli melalui brand image produk kosmetik Maybelline di Kota Denpasar.Populasi dalam penelitian ini adalah di Kota Denpasar dengan melibatkan 100 orang responden dengan metode purposive sampling.Data dikumpulkan melalui penyebaran kuisoner.Teknik analisis data yang digunakan adalah uji asumsi klasik, teknik analisis jalur (path analysis), uji sobel dan uji VAF. Hasil penelitian menemukan bahwa kredibilitas celebrity endorser berpengaruh positif dan signifikan dengan brand image.Brand image berpengaruh positif dan signifikan terhadap niat beli. Kredibilitas celebrity endorser berpengaruh positif dan signifikan terhadap niat beli. Brand image memediasi pengaruh kredibilitas celebrity endorser terhadap niat beli kosmetik Maybelline di Kota Denpasar.

Kata Kunci : kredibilitas celebrity endorser, brand image, niat beli
\end{abstract}

\begin{abstract}
This study aims to examine the influence of celebrity endorser credibility on purchase intentions through the brand image of Maybelline cosmetics products in Denpasar City. The population in this study was in the city of Denpasar by involving 100 respondents with a purposive sampling method. Data was collected through questionnaires. The data analysis technique used is the classic assumption test, path analysis technique (path analysis), sobel test and VAF test. The results of the study found that the credibility of the celebrity endorser had a positive and significant effect on the brand image. Brand image had a positive and significant effect on purchase intention. The credibility of celebrity endorsers had a positive and significant effect on purchase intention. Brand image mediates the influence of celebrity endorser's credibility on the purchase intention of Maybelline cosmetics in Denpasar City.

Keywords: celebrity endorser credibility, brand image, purchase intention
\end{abstract}




\section{PENDAHULUAN}

Produk kosmetik digunakan wanita untuk mempercantik diri dan merawat diri, baik dengan menggunakan skin care maupun make up. Wanita adalah mahluk yang identik terhadap keindahan, wanita selalu ingin tampil cantik dalam berbagai keadaan dan selalu ingin menjadi pusat perhatian bagi sekelilingnya.Hal inilah yang menjadi alasan mengapa wanita senang mempercantik diri terhadap menggunakan berbagai macam kosmetik (Indonesia Finance Today, kemenperin.go.id). Penggunaan kosmetik pada saat ini tidak hanya digunakan oleh wanita yang sudah dewasa tetapi juga digemari oleh para remaja putri pun kini sehari-hari sudah menggunakannya. Hofstede dalam kim et al. (2012) menyatakan, semakin maju suatu negara, maka masyarakat akan memperhatikan penampilannya.

Menurut data Persatuan Perusahaan Kosmetika Indonesia (Perkosmi), pada tahun 2017 penjualan kosmetik dalam negeri sebesar Rp 1,4 triliun, meningkat lebih dari dua kali lipatnya dibandingkan tahun 2016 yang sebesar Rp 36 triliun. (http//www.kemenperin.go.id). Persaingan bisnis produk kosmetika sangatlah ketat banyaknya kosmestik impor yang berlomba - lomba menyaingi kosmetik dalam negeri, hal tersebut ditunjukan terhadap data dari Kementerian Perindustrian yang menyatakan pertumbuhan kosmetik lokal Indonesia kalah besar jika dibandingkan terhadap kosmetik impor dan kosmetik brand multinasional terhadap penjualan kosmetik impor naik 30 persen itu termasuk dua kali lipat dari penjualan kosmetik Indonesia (kemenperin.go.id). 
Berdasarkan dari fenomena di atas dapat dikatakan penjualan kosmetik dikatakan tumbuh sangat pesat yang menandakan adanya perilaku niat beli produk kosmetik yang tinggi di masyarakat indonesia yang diduga sebagai salah satu penyebab munculnya terjadi niat pembelian. Tantangan lain yang dihadapi oleh perusahaan adalah saat ini konsumen lebih selektif dan teliti dalam memilih produk yang digunakan (Prayuana dan Andjarwati,2013). Perusahaan harus membuat strategi pemasaran untuk menarik konsumen agar menimbulkan niat beli terhadap strategi tersebut terhadap berbagai cara salah satunya terhadap pemberian informasi tentang produk untuk menarik perhatian dan menciptakan asosiasi positif (Pangastuti dan Purnami 2015).

Brand image yang akan tercipta oleh celebrity endorser yang dipilih nantinya tentu akan berpengaruh terhadap niat beli produk kosmetik Maybeline sehingga pemilihan celebrity endorser harus tepat sesuai terhadap brand image yang ingin diciptakan. Maybelline memiliki pesaing seperti wardah pond's, Revlon dan L'Oreal. Mereka bersaing dalam mengandalkan celebrity endorser dan brand image mereka dalam menarik konsumen untuk membeli produk kecantikan mereka. Brand image yang baik akan menimbulkan nilai-nilai emosional konsumen, oleh sebab itu perusahaan perlu untuk meningkatkan brand image mereka karena nilai emosional ini akan memicu terjadinya persepsi yang positif akan suatu produk yang akan menimbulkan niat beli (Weli, 2016).

Penggunaan selebriti untuk menyampaikan produk ke masyarakat memang terbukti mampu meningkatkan penjualan dari produsen kosmetik dan juga niat beli dari masyarakat. Menurut Pakaya (2012), penggunaan selebriti sebagai 
bintang iklan bertujuan untuk memperoleh perhatian dari masyarakat yang pada akhirnya akan mendatangkan tanggapan yang positif. Memanfaatkan celebrity sebagai endorser memang lebih mudah dalam mempengaruhi psikologis konsumsi konsumen, hal tersebut akan menciptakan persepsi positif terhadap produk yang dipromosikannya dan meningkatkan niat beli (Haryantana dan Ekawati 2015). Melihat ketersediaan konsumen untuk membeli ataupun berniat membeli biasanya di dorong oleh penggunaan selebriti yang terkenal. Terhadap itu, mampu lebih efektif menyampaikan informasi pesan dari produknya. Hollensen \& Schimmelpfennig (2013) menyatakan bahwa kontrak tokoh terkenal hampir pasti menjamin jumlah minimum perhatian konsumen, liputan media, dan kredibilitas untuk produk-produknya. Makin bermunculan selebriti-selebriti muda yang bertalenta semakin banyak juga produsen yang dapat memakai tiga sampai lima selebriti untuk satu produknya. Menurut penelitian Putra dan Giantari (2014) menyatakan semakin baik dan gencar perusahaan dalam melakukan penjualan terhadap menggunakan celebrity endorser, maka niat membeli pada suatu produk akan mengalami peningkatan.

Tabel 1.

Katagori Kosmetik Survei TOP BRAND 2016-2018

\begin{tabular}{ccccccc}
\hline Rank & \multicolumn{2}{c}{$\mathbf{2 0 1 6}$} & \multicolumn{2}{c}{$\mathbf{2 0 1 7}$} & \multicolumn{2}{c}{$\mathbf{2 0 1 8}$} \\
\hline 1 & Maybelline & $25,3 \%$ & Wardah & $19,2 \%$ & Maybelline & $22,0 \%$ \\
2 & Oriflame & $13,6 \%$ & Maybelline & $15,0 \%$ & Wardah & $19,0 \%$ \\
3 & QL & $10,0 \%$ & Revlon & $13,0 \%$ & Oriflame & $11,5 \%$ \\
4 & Revlon & $7,9 \%$ & Sariayu & $9,6 \%$ & Revlon & $11,4 \%$ \\
5 & Pixy & $7,1 \%$ & Oriflame & $6,9 \%$ & QL & $9,5 \%$ \\
\hline \multicolumn{2}{l}{ Sumber $:$ Topbrand-award tahun $2016-2018$} &
\end{tabular}

Tabel 1. menunjukkan kosmetik Maybelline tahun 2016-2018 dimana 2016 berada pada tingkat pertama sebesar 25,3 persen, sedangkan di tahun 2017 Maybelline mengalamai penurunan sebesar yaitu 15 persen dan kembali 
mengalami peningkatan sebesar 22,0 persen. Penurunan ini terjadi dikarenakan banyaknya pesaing baru kosmetik Maybelline di Indonesia.Hal ini dapat mengidentifikasikan bahwa niat beli masyarakat Maybelline mulai berkurang.

Strategi pemasaran yang dapat dilakukan oleh perusahaan untuk memberikan informasi tentang produk kepada konsumen adalah melalui periklanan (Silvera 2004). Kiswalini dan Nurcahya (2014) menyatakan bahwa penggunaan celebrity endorser sebagai salah satu cara kreatif dalam beriklan yang diharapkan dapat menarik perhatian konsumen dan meningkatkan kesadaran produk. Agar barang atau jasa yang ditawarkan perusahaan melalui media iklan tersebut memiliki daya tarik bagi calon konsumen untuk dibeli, biasanya diperlukan dukungan tokoh terkenal ataupun celebrity yang memiliki kredibilitas dalam menyampaikan pesan lewat iklan sehingga diharapkan dapat menimbulkan dampak dan kesadaran yang besar baik di pasar target maupun masyarakat luas. Bagi perusahaan pemilihan seorang celebrity untuk dijadikan bintang iklan penting untuk diperhatikan karena seorang celebrity endorser dapat meningkatkan atau menurunkan nilai dari suatu produk yang dipasarkan, dan niat beli konsumen dapat meningkat apabila konsumen memperoleh manfaat lebih dari apa yang konsumen bayar untuk sebuah produk (Hansudoh, 2012).

Maybelline adalah produk kosmetik yang didirikan pada tahun 1951 oleh T.L William di New York, amerika serikat. Nama Maybelline merupakan gabungan dari maybel (nama saudara perempuan T.L William yang menjadi inspirasi produknya) perusahaan ini diambil alih oleh L'Oreal Group sejak tahun 1996 hingga saat ini. Maybelline New York adalah brand make up no 1 di dunia, 
terdepan dalam kualitas dan inovasi terhadap identitas New York yang modern dan harga terjangkau. Bersamaan terhadap lahirnya slogan "Maybe It's Maybelline" di tahun 1991, brand ini menjadikan kecantikan terjangkau bagi wanita di berbagai penjuru dunia, sehingga setiap wanita berkesempatan untuk memaksimalkan potensi kecantikkan mereka. Melalui berbagai komunikasi terhadap ikon-ikon cantik dan mempesona dari berbagai etnis termasuk Indonesia (www.loreal.co.id).

Sherina Munaf seorang penyanyi serta aktris, merupakan celebrity endorser Maybelline pertama dari Indonesia yang dipilih pada tahun 2010.Produk Maybelline yang di iklankan oleh Sherina antara lain adalah Fruity Jelly Lipgloss, Clear Smooth Mineral BB Cream, Clear \& Smooth Prossed Powder, dan Clear \& Smooth All In One. Selain Sherina, aktris Pevita Pearce ditunjuk sebagai celebrity endorser Maybelline pada acara peluncuran produk baru dari Maybelline pada tanggal 04 November 2017. Alasan Pevita Pearce dipilih sebagai endoser Maybelline yang baru, karenaseperti yang kita ketahui, Pevita Pearce adalah sosok selebriti muda yang enerjik, penuh semangat, penuh impian, berprestasi dan banyak citra positif lainnya yang menjadi daya tarik tersendiri bagi perusahaan Maybelline untuk menggunakannya sebagai endorser terhadap memanfatkan metode periklanan yang semakin canggih (tribunews.com). Produk Maybelline yang di iklankan oleh Pevita Pearce antara lain adalah Maybelline New York colorshow dan Maybelline white superfresh, celebrity endorser yang dipilih sebagai fokus utama dalam penelitian ini adalah Pevita Pearce, karena sebagai celebrity endorser Maybelline Pevita Pearce terbilang terkenal di kalangan remaja 
dan sedang gencar di promosikan oleh pihak Maybelline di Indonesia. Kurniawan (2012), dan Jalilvand dan Samci (2012) pada penelitiannya menunjukan bahwa brand image atau citra merek memiliki pengaruh yang signifikan terhadap niat beli membeli pada seseorang.Rahma dalam kurniawan (2012) mengemukakan bahwa brand image akan berpengaruh langsung terhadap tingginya niat beli terhadap suatu produk.

Chi et al. (2009) menyatakan kredibilitas seorang celebrity endorser yaitu dapat dipercaya, keahlian dan daya tarik dapat menarik perhatian di mata konsumen dalam waktu yang singkat dan memiliki pengaruh signifikat terhadap niat beli. Semakin baik kredibilitas, daya tarik keahlian, kepercayaan dari seorang celebrity maka semakin baik juga pengaruhnya terhadap brand image suatu produk dan sebaliknya.Pada penelitian sebelumnya, Hansudoh (2012) menyebutkan bahwa kredibilitas celebrity endorser berpengaruh positif dan signifikan terhadap niat beli. Sallam (2011) menunjukkan hasil yang sama bahwa kredibilitas celebrity endorser memiliki pengaruh yang positif pada niat beli konsumen di Arab Saudi. Hasil penelitian yang juga mendapatkan hasil yang sama terhadap penelitian diantara lain oleh: Rodriguez (2008), van Der Waldt et al. (2009), Sallam (2011), Apejoye (2013), Khan (2013), dan Putra dan Giantari (2014).

Perbedaan hasil terhadap hasil-hasil studi sebelumnya, temuan penelitian yang dilakukan oleh Stephanie dkk. (2013) menggambarkan bahwa kredibilitas celebrity endorser tidak berpengaruh secara langsung pada niat beli melainkan melalui daya tarik iklan (advertising appeal) dan efek iklan (advertising effect). 
Hal tersebut juga didukung oleh hasil studi Sertoglu et al. (2014) yang mengindikasikan bahwa juru bicara yang diciptakan (created spokesperson) memiliki kredibilitas yang lebih tinggi daripada celebrity endorser.

Penelitian Amanda (2014) menyatakan bahwa terdapat pengaruh antara kredibilitas celebrity endorserterhadapbrand image, yaitu penggunaan celebrity endorser lebih efektif menghasilkan respon yang positif terhadapbrand image, sekaligus meningkatkan keinginan untuk membeli. Hasil penelitian Nisa dan Amal (2013) serta Sari dan Djatikusuma (2013) kredibilitas seorang celebrity endorserberpengaruh signifikan dan positif terhadap brand image karenapenggunaan celebrity endorser yang tepat dapat meningkatkan brand image suatu produk atau layanan dan dapat meningkatkan niat beli. Hasil penelitian kredibilitas seorang celebrity endorser berpengaruh positif dan signifikan terhadap brand image didapatkan dari penelitianRini dan Astuti (2012) Nisa dan Amal (2013) serta Sari dan Djatikusuma (2013).

Tanomi (2012) dalam penelitiannya berpendapat bahwa brand image suatu produk dapat mempengaruhi sikap konsumen yang merupakan paradigma pemrosesan informasi dan menggunakan informasi dalam proses pembuatan keputusan. Kurniawan (2012) mengemukakan bahwa brand image akan berpengaruh langsung terhadap tingginya minat beli terhadap suatu produk karena konsumen akan memiliki alasan untuk membeli atau menggunakan produk terhadapbrand image yang dianggap khalayak sebagai produk yang baik, berkualitas, dan dipakai oleh orang terkenal. Jalilvand dan Samei (2012) pada 
penelitiannya menunjukkan bahwa brand image atau citra merek memiliki pengaruh yang signifikan terhadap niat membeli pada seseorang.

Penelitian Ruslim dan Andrew (2012), Wahyuni dan Suparna (2014), serta Wang dan Tsai (2014) diketahui bahwa kredibilitas seorang celebrity endorsememiliki pengaruh yang positif dan signifikan terhadap brand image, dan mempengaruhi purchase intention konsumen melalui brand image suatu produk. Berdasarkan pada fenomena dan hasil - hasil penelitian sebelumnya yang telah dipaparkan diatas, permasalahan dalam penelitian ini adalah untuk mengetahui berhasil atau tidaknya perusahaan Maybelline dalam memanfaatkan Kredibilitas celebrity endorser dan penciptaan brand image untuk menimbulkan niat beli pada konsumen, serta bagaimana peran brand image dalam memediasi kredibilitas celebrity endorser terhadap niat beli produk kosmetik Maybelline di Kota Denpasar.

Beranjak dari hal tersebut untuk mengetahui seberapa besar niat yang dimiliki konsumen Kota Denpasar untuk melakukan pembelian kosmetik Maybelline, maka dilakukanlah penelitian terhadap menggunakan metode pra survei terhadap menyebarkan kuisioner sementara kepada 20 orang responden.Jawaban setiap item diberi skor terhadap interval 1-5, dimana $1=$ sangat tidak setuju (STS), 2 = kurang setuju (KS), 3 = setuju (S),4 = Sangat Setuju (ST),5 = amat sangat setuju (ASS). Rangkumsn hasil pra survei disajikan pada Tabel 2.

Berdasarkan beberapa pernyataan yang diajukan 20 orang responden, 7 responden memiliki daya tarik karena kemampuan dalam mengiklankan dan 
didukung terhadap keeksisan selebrity endorser di media sosial dan juga didukung terhadap fisik yang menarik dalam membintangi produk kosmetik Maybelline, 4 responden menyatakan keyakinan melihat produk kosmetik Maybelline lebih unggul dari produk sejenis lainnya dan 9 responden sangat tertarik untuk mencoba produk kosmetik Maybelline.

Tabel 2.

Hasil Pernyataan Pra-Survei

\begin{tabular}{|c|c|c|c|c|}
\hline No. & Variabel & Pernyataan & Pengukuran & $\begin{array}{c}\text { Jumlah } \\
\text { Responden }\end{array}$ \\
\hline 1. & $\begin{array}{l}\text { Kredibilitas } \\
\text { Celebrity } \\
\text { endorser }\end{array}$ & $\begin{array}{l}\text { Saya melihat Celebrity } \\
\text { endorser memiliki daya tarik } \\
\text { dalam membintangi produk } \\
\text { kosmetik Maybelline }\end{array}$ & $\begin{array}{c}4(\mathrm{~S}) \\
3(\mathrm{ST})\end{array}$ & 7 \\
\hline 2 & Brand image & $\begin{array}{l}\text { Terdapat keyakinan ketika } \\
\text { saya melihat produk } \\
\text { kosmetik Maybelline yang } \\
\text { dibintangi oleh Celebrity } \\
\text { endorser lebih unggul dari } \\
\text { produk sejenis lainnya }\end{array}$ & $\begin{array}{l}2(\mathrm{~S}) \\
2(\mathrm{~S})\end{array}$ & 4 \\
\hline 3. & Niat Beli & $\begin{array}{l}\text { Saya tertatik untuk mencoba } \\
\text { produk kosmetik Maybelline }\end{array}$ & $\begin{array}{l}5(\mathrm{ASS}) \\
4(\mathrm{~S})\end{array}$ & 9 \\
\hline
\end{tabular}

Sumber:Data diolah, 2018

Maulana dalam Amanda (2014) menyatakan bahwa terdapat pengaruh antara kredibilitas celebrity endorserterhadapbrand image, yaitu penggunaan celebrity endorser lebih efektif menghasilkan respon yang positif terhadap brand image, sekaligus meningkatkan keinginan untuk membeli.Menurut Nisa dan Amal (2013) serta Sari dan Djatikusuma (2013) kredibilitas seorang celebrity endorser berpengaruh signifikan dan positif terhadap brand image karenapenggunaan celebrity endorser yang tepat dapat meningkatkan brand image suatu produk atau layanan dan dapat meningkatkan niat beli. 
Hasil penelitian Rini dan Astuti (2012) menyatakan bahwa kredibilitas celebrity endorser berpengaruh secara positif dan signifikan terhadap pembentukan brand image. Berdasarkan hal tersebut dirumuskan hipotesis sebagai berikut:

$\mathrm{H}_{1}$ : Kredibilitas celebrity endorser berpengaruh positif dan signifikan terhadap brand image.

Shafiq et al. (2011) menyatakan bahwa kredibilitas celebrity endorser merupakan sosok orang yang menarik, mampu mengiklankan produk, dan memiliki kredibilitas yang baik, sehingga dapat menumbuhkan niat beli pada orang yang melihat iklan dan untuk membeli produk yang diiklankan. Pada penelitian sebelumnya, Hansudoh (2012) menyebutkan bahwa kredibilitas celebrity endorse rberpengaruh positif dan signifikan terhadap purchase intention. Indraswari dan Pramudana (2014) menemukan bahwa kredibilitas celebrity endorser berpengaruh positif terhadap niat konsumen wanita untuk membeli produk pakaian wanita melalui media online. Putra dan Giantari (2014) menyatakan, semakin baik dan gencar perusahaan dalam melakukan penjualan terhadap menggunakan celebrity endorser, maka niat membeli sepeda motor automatic merek Honda akan mengalami peningkatan. Hasil penelitian Sallam (2011) menunjukkan hasil bahwa kredibilitas celebrity endorser memiliki pengaruh yang positif pada niat beli konsumen di Arab Saudi. Temuan yang samaditunjukkan pada studi yang dilakukan oleh Zafar (2012), Apejoye (2013) serta Khan (2013) juga menunjukkan bahwa kredibilitas celebrity endorser mempengaruhi niat beli konsumen. 
Bertentangan terhadap hasil-hasil studi sebelumnya, temuan penelitian yang dilakukan oleh Stephaniedkk.(2013) menggambarkan bahwa kredibilitas celebrity endorser tidak berpengaruh secara langsung pada niat beli melainkan melalui daya tarik iklan (advertising appeal) dan efek iklan (advertising effect). Hal tersebut juga didukung oleh hasil studi Sertoglu et al. (2014) yang mengindikasikan bahwa juru bicara yang diciptakan (created spokesperson) memiliki kredibilitas yang lebih tinggi daripada celebrity endorser. Berdasarkan uraian tersebut dirumuskan hipotesis sebagai berikut.

$\mathrm{H}_{2}$ : Kredibilitas celebrity endorser berpengaruh positif dan signifikan terhadap niat beli.

Tanomi (2012) berpendapat bahwa brand image suatu produk dapat mempengaruhi sikap konsumen yang merupakan paradigma pemrosesan informasi dan menggunakan informasi dalam proses pembuatan keputusan. Rahma dalam Kurniawan (2012) mengemukakan bahwa brand image akan berpengaruh langsung terhadap tingginya minat beli terhadap suatu produk karena konsumen akan memiliki alasan untuk membeli atau menggunakan produk terhadapbrand image yang dianggap khalayak sebagai produk yang baik, berkualitas, dan dipakai oleh orang terkenal.

Berdasarkan penelitian yang dilakukan oleh Ruslim dan Andrew (2012), Jalilvand dan Samei (2012), Wahyuni dan Suparna (2014), Wang dan Tsai (2014), didapatkan hasil bahwa terdapat pengaruh yang positif dan signifikan antara brand image dan purchase intention. Berdasarkan hal tersebut dirumuskan hipotesis sebagai berikut.

$\mathrm{H}_{3}$ : Brand image berpengaruh positif dan signifikan terhadap niat beli. 
Rini dan Astuti (2012) menyatakan bahwa kredibilitas celebrity endorser berpengaruh secara positif dan signifikan terhadap pembentukan brand image. Suatu produk yang memiliki brand image yang baik merupakan salah satu cara yang efektif di dalam menjaring konsumen, karena konsumen terhadap sadar atau tidak sadar akan memilih suatu produk yang memiliki brand image yang positif, sehingga tercipta persepsi yang baik di mata konsumenyang pada akhirnya menciptakan loyalitas terhadap suatu merek produk tertentu.

Berdasarkan hasil penelitian Ruslim dan Andrew (2012), Wahyuni dan Suparna (2014), serta Wang dan Tsai (2014) diketahui bahwa kredibilitas seorang celebrity endorser memiliki pengaruhyang positif dan signifikan terhadap brand image, dan mempengaruhi purchase intention konsumen melalui brand image suatu produk. Berdasarkan hal tersebut dirumuskan hipotesis sebagai berikut.

$\mathrm{H}_{4}$ : Brand image memediasi pengaruh kredibilitas celebrity endorser terhadap niat beli.

\section{METODE PENELITIAN}

Penelitian ini dilakukan di Kota Denpasar. Kota Denpasar merupakan wilayah terhadap penduduk yang padat dan memiliki kesadaran yang tinggi akan kebutuhan perawatan wajah dan tubuh terhadap kosmetik. Lokasi ini dipilih karena Kota Denpasar merupakan Ibu Kota Provinsi Bali terhadap populasi tertinggi di provinsi Bali, yaitu sebanyak 788.589 jiwa (BPS, 2018). Menurut data yang didapat dari Badan Pusat Statistik Provinsi Bali (2018), Kota Denpasar juga merupakan daerah terhadap laju pertumbuhan ekonomi tertinggi di Provinsi Bali yaitu sebesar $6.50 \%$. Sehingga lokasi ini dianggap relevan dan menarik untuk dipilih menjadi lokasi penelitian. Objek penelitiannya ini adalah konsumen yang 
mengetahui iklan kosmetik Maybelline dan berniat membeli kosmetik Maybelline. Adapun objek dalam peneitian ini yaitu kredibilitas celebrity endorser, brand image dan niat beli konsumen pada kosmetik Maybelline di Kota Denpasar.

Tabel 3.

Indikator Variabel Penelitian

\begin{tabular}{cll}
\hline \multicolumn{1}{c}{ Variabel } & \multicolumn{1}{c}{ Indikator } & \multicolumn{1}{c}{ Sumber } \\
\hline & 1. Memiliki Daya tarik (X.1) & \\
Kredibilitas Celebrity & 2. Dapat Dipercaya (X.2) & \\
endorser(X) & 3. Memiliki Keahlian (X.3) & \\
& 1.Daya ingat konsumen akan merek (M.1) & \\
2.Kualitas Produk (M.2) & Schiffman dan Kanuk \\
Brand image (M) & $\begin{array}{l}\text { 3.Citra produk (M.3) } \\
\text { 4.Keunikan (M.4) }\end{array}$ & $\begin{array}{l}\text { (2006), Shimp (2014) } \\
\text { dan Hamdina (2015). }\end{array}$ \\
& $\begin{array}{l}\text { 1.Mencari informasi mengenai produk (Y.1) } \\
\text { Niat Beli(Y) }\end{array}$ & \\
& $\begin{array}{l}\text { 2.Keinginan untuk segera membeli (Y.2) } \\
\text { 3.Memiliki preferensi bahwa produk ini yang } \\
\text { dicari(Y.3) }\end{array}$ & Tanomi (2012) \\
& & \\
& &
\end{tabular}

Sumber: Data diolah, 2018

Populasi dalam penelitian ini adalah konsumen yang berdomisili di Kota Denpasar, yang sudah pernah menonton iklan produk kosmetik Maybelline dan yang berniat melakukan pembelian kosmetik Maybelline. Penelitian ini menggunakan 10 indikator yang berarti sampel yang diperlukan minimal 50 (5x10) dan maksimal 100 (10x10). Karena keterbatasan peneliti maka Penelitian ini menggunakan 100 sampel.Dalam penelitian ini teknik analisis yang digunakan adalah teknik analisis jalur (path analysis).

Persamaan Sub-struktural 1

$\mathrm{M}=\beta_{1} \mathrm{X}+\mathrm{e}_{1}$

Persamaan Sub-struktural 2

$\mathrm{Y}=\beta_{2} \mathrm{X}+\beta_{3} \mathrm{M}+\mathrm{e}_{2}$ 
Keterangan :

$$
\begin{aligned}
& \mathrm{X} \quad=\text { Kredibilitaas Celebrity endorser } \\
& \mathrm{M} \quad=\text { Brand image } \\
& \mathrm{Y} \quad=\text { Niat Beli } \\
& \beta_{1}, \beta_{2}, \beta_{3}=\text { koefisien masing-masing variabel } \\
& \text { e } \quad=\text { error }
\end{aligned}
$$

\section{HASIL DAN PEMBAHASAN}

Perhitungan koefisien path dilakukan terhadap analisis regresi melalui

\begin{tabular}{|c|c|c|c|c|c|c|}
\hline \multicolumn{2}{|c|}{ Variabel } & \multicolumn{2}{|c|}{$\begin{array}{c}\text { Unstandardized } \\
\text { Coefficients }\end{array}$} & \multirow{2}{*}{$\begin{array}{c}\begin{array}{c}\text { Standardized } \\
\text { Coefficients }\end{array} \\
\text { Beta }\end{array}$} & \multirow[t]{2}{*}{$\begin{array}{c}\mathrm{t} \\
\text { hitung }\end{array}$} & \multirow[t]{2}{*}{$\begin{array}{l}\text { Sig. } \\
\text { uji t }\end{array}$} \\
\hline & & B & $\begin{array}{c}\text { Std. } \\
\text { Error }\end{array}$ & & & \\
\hline (Constant) & & 5,296 & 1,346 & & 3,933 & 0,000 \\
\hline $\begin{array}{l}\text { Kredibilitas } \\
\text { endorser (X) }\end{array}$ & Celebrity & 0,782 & 1,09 & 0,588 & $\begin{array}{c}7,19 \\
1\end{array}$ & 0,000 \\
\hline R Square & & 0,345 & & & & \\
\hline F Statistik & & 51,710 & & & & \\
\hline Signifikansi Uji & & 0,000 & & & & \\
\hline
\end{tabular}
software SPSS 20.0 for Windows, diperoleh hasil yang ditunjukan pada Tabel 2. berikut.

Tabel 4.

Hasil Analisis Jalur I

Sumber: Data diolah, 2018

Berdasarkan hasil analisis jalur substruktur 1 seperti yang disajikan pada

Tabel 4, maka dapat dibuat persamaan struktural sebagai berikut :

$\mathrm{M}=\beta_{1} \mathrm{X}+\mathrm{e}_{1}$

$\mathrm{M}=0,588 \mathrm{X}$

Nilai koefisien regresi variabel kredibilitas celebrity endorser bernilai positif terhadap nilai signifikansi uji t kurang dari 0,05. Hal ini menunjukkan bahwa variabel kredibilitas celebrity endorser memiliki pengaruh positif yang signifikan terhadap variabel brand image. Besarnya pengaruh variabel bebas terhadap variabel terikat yang ditunjukkan oleh nilai determinasi total (R Square) 
sebesar 0,345mempunyai arti bahwa sebesar 34,5\% variasi brand image dipengaruhi oleh variasikredibilitas celebrity endorser, sedangkan sisanya sebesar $65,5 \%$ dijelaskan oleh faktor lain yang tidak dimasukkan ke dalam model.

Tabel 5.

Hasil Analisis Jalur II

\begin{tabular}{lccccc}
\hline \multicolumn{1}{c}{ Variabel } & \multicolumn{2}{c}{$\begin{array}{c}\text { Unstandardized } \\
\text { Coefficients }\end{array}$} & $\begin{array}{c}\text { Standardized } \\
\text { Coefficients }\end{array}$ & t hitung & $\begin{array}{c}\text { Sig. } \\
\text { uji t }\end{array}$ \\
\hline & $\mathrm{B}$ & Std. Error & Beta & & \\
(Constant) & 1,727 & 1,017 & & 1,698 & 0,093 \\
Celebrity endorser & 0,303 & 0,094 & 0,278 & 3,212 & 0,002 \\
(X) & & & & & \\
Brand image (M) & 0,430 & 0,071 & 0,525 & 6,060 & 0,000 \\
R Square & 0,524 & & & & \\
F Statistik & 53,412 & & & & \\
Signifikansi Uji F & 0,000 & & & &
\end{tabular}

Berdasarkan hasil analisis jalur substruktur 2 seperti yang disajikan pada Tabel 5, maka dapat dibuat persamaan struktural sebagai berikut :

$\mathrm{Y}=\beta_{2} \mathrm{X}+\beta_{3} \mathrm{M}+\mathrm{e}_{2}$

$\mathrm{Y}=0,278 \mathrm{X}+0,525 \mathrm{M}$

Nilai koefisien regresi masing-masing variabel bebas bernilai positif terhadap nilai signifikansi uji t kurang dari 0,050. Hal ini menunjukkan bahwa semua variabel bebas memiliki pengaruh positif yang signifikan terhadap variabel terikat.Besarnya pengaruh variabel bebas terhadap variabel terikat yang ditunjukkan oleh nilai determinasi total (R Square) sebesar 0,524 mempunyai arti bahwa sebesar 52,4\% variasi Niat Beli dipengaruhi oleh variasikredibilitas celebrity endorser dan brand image, sedangkan sisanya sebesar 47,6\% dijelaskan oleh faktor lain yang tidak dimasukkan ke dalam model. 
Berdasarkan model substruktur 1 dan substruktur 2, maka dapat disusun model diagram jalur akhir. Sebelum menyusun model diagram jalur akhir, terlebih dahulu dihitung nilai standar eror sebagai berikut :

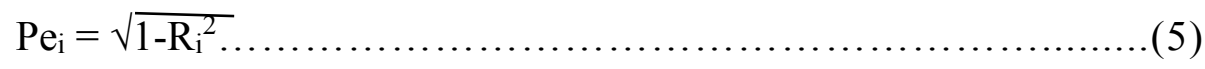

$$
\begin{aligned}
& \mathrm{Pe}_{1}=\sqrt{1-\mathrm{R}_{1}^{2}} \\
& =\sqrt{1-0,345}=0,809 \\
& \begin{aligned}
\mathrm{Pe}_{2} & =\sqrt{1-\mathrm{R}_{2}{ }^{2}} \ldots \ldots \ldots \ldots \ldots \ldots \\
& =\sqrt{1-0,524}=0,689
\end{aligned}
\end{aligned}
$$

Berdasarkan perhitungan pengaruh error (Pei), didapatkan hasil pengaruh error $\left(\mathrm{Pe}_{1}\right)$ sebesar 0,809 dan pengaruh error $\left(\mathrm{Pe}_{2}\right)$ sebesar 0,689. Hasil koefisien determinasi total adalah sebagai berikut :

$$
\begin{aligned}
& \mathrm{R}^{2}{ }_{\mathrm{m}}=1-\left(\mathrm{Pe}_{1}\right)^{2}\left(\mathrm{Pe}_{2}\right)^{2} \\
& =1-(0,809)^{2}(0,689)^{2} \\
& =1-(0,654)(0,475) \\
& =1-0,310=0,69
\end{aligned}
$$

Nilai determinasi total sebesar 0,69 mempunyai arti bahwa sebesar $69 \%$ variasi Niat Beli dipengaruhi oleh variasi Kredibilitas Celebrity endorser (X)danBrand image, sedangkan sisanya sebesar 31\% dijelaskan oleh faktor lain yang tidak dimasukkan ke dalam model. Berdasarkan hasil analisis pengaruh kedibilitas celebrity endorser terhadap brand imagediperoleh nilai Signifikansi sebesar 0,000terhadap nilai koefisien beta 0,588. Nilai Signifikansi 0,000<0,05 mengindikasikan bahwa $\mathrm{H}_{0}$ ditolak dan $\mathrm{H}_{1}$ diterima. Hasil ini mempunyai arti 
bahwa kredibilitas celebrity endorser berpengaruh positif dan signifikan terhadap brand image pada produk kosmetik Maybelline di Kota Denpasar.

Berdasarkan hasil analisis pengaruh kredibilitas celebrity endorserterhadap niat belidiperoleh nilai Signifikansi sebesar 0,002terhadap nilai koefisien beta 0,278. Nilai Signifikansi $0,002<0,05$ mengindikasikan bahwa $\mathrm{H}_{0}$ ditolak dan $\mathrm{H}_{2}$ diterima. Hasil ini mempunyai arti bahwa kredibilitas celebrity endorserberpengaruh positif dan signifikan terhadap niat beli padaproduk kosmetik Maybelline di Kota Denpasar.

Berdasarkan hasil analisis pengaruh brand image terhadap niat beli diperoleh nilai Signifikansi sebesar 0,000 terhadap nilai koefisien beta 0,525. Nilai Signifikansi $0,000<0,05$ mengindikasikan bahwa $\mathrm{H}_{0}$ ditolak dan $\mathrm{H}_{3}$ diterima. Hasil ini mempunyai arti bahwa brand image berpengaruh positif dan signifikan terhadap niat Beli produk kosmetik Maybelline di Kota Denpasar.

Tabel 6.

Pengaruh Langsung dan Pengaruh Tidak Langsung serta Pengaruh Total Kredibilitas Celebrity endorser (X), Brand image(M), dan Niat Beli(Y)

\begin{tabular}{|c|c|c|c|}
\hline $\begin{array}{c}\text { Pengaruh } \\
\text { Variabel }\end{array}$ & $\begin{array}{l}\text { Pengaruh } \\
\text { Langsung }\end{array}$ & $\begin{array}{l}\text { Pengaruh Tidak Langsung Melalui Brand } \\
\text { image } \\
\text { (M) }\left(\beta_{1 \mathrm{x}} \beta_{3}\right)\end{array}$ & Pengaruh Total \\
\hline $\mathrm{X} \rightarrow \mathrm{M}$ & 0,588 & - & 0,588 \\
\hline $\mathrm{X} \rightarrow \mathrm{Y}$ & 0,278 & 0,309 & 0,587 \\
\hline $\mathrm{M} \rightarrow \mathrm{Y}$ & 0,525 & - & 0,525 \\
\hline
\end{tabular}

Tabel 6. menunjukkan bahwa pengaruh langsung kredibilitas celebrity endoserterhadap brand image adalah sebesar 0,588. Pengaruh langsung variabel kredibilitas celebrity endorser terhadap niat beli sebesar 0,278. Pengaruh langsung variabel Brand image terhadap Niat Beli sebesar 0,525. Hal ini berarti bahwa variabel kredibilitas celebrity endorser lebih besar dipengaruhi oleh brand 
image dari pada kredibilitas celebrity endorser. Sedangkan, pengaruh tidak langsung variabel kredibilitas celebrity endorser terhadap niat beli melalui brand image sebesar 0,309. Jadi pengaruh total variabel kredibilitas celebrity endorser terhadap niat beli melalui brand image adalah sebesar 0,588.

Uji sobel merupakan alat analisis untuk menguji signifikansi dari pengaruh tidak langsung antara variabel independen terhadap variabel dependen yang dimediasi oleh variabel mediator. Uji Sobel dirumuskan terhadap persamaan berikut dan dapat dihitung terhadap menggunakan aplikasi Microsoft Excel 2010. Bila nilai kalkulasi Z lebih besar dari 1,96 (terhadap tingkat kepercayaan 95 persen), maka variabel mediator dinilai secara signifikan memediasi pengaruh antara variabel terikat dan variabel bebas. Untuk menguji signifikansi pengaruh tidak langsung maka nilai $\mathrm{z}$ dari koefisien ab dihitung terhadap rumus sebagai berikut :

$$
\begin{aligned}
& S_{a b}=\sqrt{\left(0,430^{2}\right)}(1,09)^{2}+(0,782)^{2}(0,071)^{2}+(1,09)^{2}(0,071)^{2} \\
& S_{a b}=0,083
\end{aligned}
$$

\section{Keterangan :}

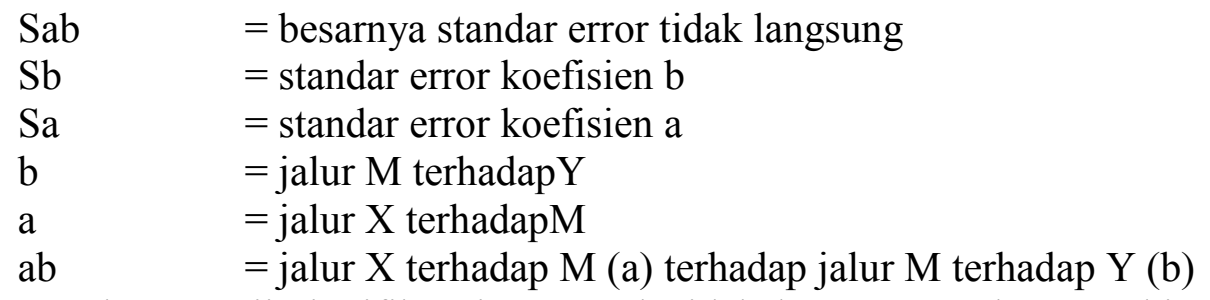

Untuk menguji signifikansi pengaruh tidak langsung maka menghitung nilai z dari koefisien ab terhadap rumus sebagai berikut :

$$
\begin{aligned}
& Z=\frac{a b}{S a b} \ldots \ldots \ldots \\
& Z=\frac{0,782 \times 0,43}{0,083}
\end{aligned}
$$




\section{$Z=4,028$ terhadap signifikansi 0,000}

Oleh karena $\mathrm{Z}$ hitung sebesar 4,028> 1,96. Artinya brand image(M) merupakan variabel yang memediasi kredibilitas celebrity endorser(X) terhadapniat beli (Y) produk kosmetik maybelline di Kota Denpasar atau terhadap kata lain kredibilitas celebrity endorser berpengaruh secara tidak langsung terhadap niat beli secara signifikan melalui brand image sebagai variabel mediasi.

Hasil pengujian mediasi terhadap metode VAF dalam penelitian ini telah memenuhi beberapa persyaratan yaitu, pertama, pengaruh langsung ditemukan signifikan (a) saat variabel Brand image (M) belum dimasukkan ke dalam model. Kedua, setelah variabel Brand image (M) dimasukkan ke dalam model, maka pengaruh tidak langsung ( $\mathrm{b}$ x c) ditemukan pula signifikan.Jalur yaitu $\mathrm{b}$ dan $\mathrm{c}$ juga signifikan. Ketiga, menghitung Variance Accounted For (VAF) terhadap rumus:

$$
\begin{aligned}
\mathrm{VAF}= & \frac{b \times c}{(a+b \times c)} \ldots \ldots \ldots \ldots \ldots \ldots \\
\mathrm{VAF}= & \frac{0,588 \times 0,525}{(0,586+(0,588 \times 0,525)} \\
& =0,345 \text { atau } 34,5 \text { persen. }
\end{aligned}
$$

Nilai VAF (34,5 persen) lebih dari 20 persen, maka dapat dijelaskan bahwa ada efek mediasi. Terhadap demikian, maka hipotesis yang menyatakan bahwa brand image memediasi pengaruh kredibilitas celebrity endorser terhadap niat beli diterima.Pengaruhkredibilitas celebrity endorser terhadap brand imagedalam penelitian ini di peroleh nilai koefisien beta sebesar 0,588terhadap tingkat signifikasi $0,000<0,05$, sehingga $\mathrm{H}_{0}$ ditolak dan $\mathrm{H}_{1}$ diterima, yang mengindikasi bahwa kredibilitas celebrity endorserberpengaruh positif dan signifikan terhadap 
brand image. Hasil tersebut menunjukan bahwa semakin pelanggan mengingat suatu merek terhadap melihat keahlian dan daya tarik celebrity endorser dalam penyampaian pesan maka akan meningkatkan brand image pada kosmetik Maybelline.

Hasil rangkuman penilaian responden yang disajikan dalam deskripsi variabel penelitian menunjukan bahwa penilaian responden terhadap variabel kredibilitas celebrity endorser berada dalam katagori baik, sehingga menghasilkan variabel brand image berada dalam katagori baik. Responden mengingat suatu merek yang di iklankan oleh selebriti dalam penyampaian informasi mengenai produk kosmetik Maybelline. Hasil penelitian ini diperkuat oleh penelitian sebelumnya yang dilakukan oleh Nisa dan Amal (2013), Sari dan Djatikusuma (2013) serta Rini dan Astuti (2012) yang menyatakan bahwa kredibilitas celebrity endorser berpengaruh positif dan signifikan terhadap brand image.

Pengaruh kredibilitas celebrity endorser terhadap niat beli dalam penelitian ini di peroleh nilai koefisien beta sebesar 0,278terhadap tingkat signifikasi $0,002<$ 0,05, sehingga $\mathrm{H}_{0}$ ditolak dan $\mathrm{H}_{2}$ diterima, yang mengindikasi bahwa kredibilitas celebrity endorserberpengaruh positif dan signifikan terhadap niat beli. Hasil tersebut menunjukan bahwa semakin tertarik pelanggan terhadap keahlian dari celebrity endorser makaakan semakin tinggi niat beli dari pelanggan pada kosmetik Maybelline.

Hasil rangkuman penilaian responden yang disajikan dalam deskripsi variabel penelitian menunjukan bahwa penilaian responden terhadap variabel 
kredibilitas celebrity endorser berada dalam katagori baik, sehingga menghasilkan variabel niat beli berada dalam katagori sangat baik.Responden tertarik bahwa penyampaian informasi tentang produk yang menimbulkan daya tarik dilakukan celebrity endorser akan menimbulkan niat beli dan produk kosmetik Maybelline. Hasil penelitian ini diperkuat oleh penelitian sebelumnya yang dilakukan oleh Sallam (2011), Zafar (2012), Apejoye (2013) serta Khan (2013) yang menyatakan bahwa kredibilitas celebrity endorser berpengaruh positif dan signifikan terhadap niat beli.

Pengaruh brand image terhadap niat beli dalam penelitian ini di peroleh nilai koefisien beta sebesar 0,525terhadap tingkat signifikasi $0,000<0,05$, sehingga $\mathrm{H}_{0}$ ditolak dan $\mathrm{H}_{3}$ diterima, yang mengindikasi bahwa brand image berpengaruh positif dan signifikan terhadap niat beli. Hasil tersebut menunjukan bahwa semakin pelanggan mengingat suatu merek maka akan semakin tinggi niat untuk membeli pada kosmetik Maybelline.

Hasil rangkuman penilaian responden yang disajikan dalam deskripsi variabel penelitian menunjukan bahwa penilaian responden terhadap variabel brand image berada dalam katagori baik, sehingga menghasilkan variabel niat beli berada dalam katagori sangat baik.Responden memiliki niat beli tinggi pada kosmetik Maybelline karena citra merek produk tersebut sesuai terhadap yang dicari.Hasil penelitian ini diperkuat oleh penelitian sebelumnya yang dilakukan oleh Ruslim dan Andrew (2012), Jalilvand dan Samei (2012), Wahyuni dan Suparna (2014), Wang dan Tsai (2014), serta Subiyanto (2013) yang menyatakan bahwa brand imageberpengaruh positif dan signifikan terhadap niat beli. 
Peran brand imagedalam memediasi pengaruhkredibilitas celebrity endorser terhadap niat belipada kosmetik Maybelline telah diuji dalam penelitian ini. Hasil uji pengaruh kredibilitas celebrity endorser terhadap niat beli bernilai 0,278, kemudian pengaruh tidak langsungnya terhadap adanya brand image di dalamnya menjadi sebesar 0,309terhadap pengaruh totalnya dari semua variabel menjadi sebesar 0,578. Hasil tersebut menunjukkan bahwa brand imagememediasi pengaruh kredibilitas celebrity endorser terhadap niat beli. Uji Sobel yang telah dihitung memperkuat hasil tersebut terhadap nilai koefisien $\mathrm{z}$ yang diperoleh adalah 4,029>1,96 sehingga $\mathrm{H}_{0}$ ditolak dan $\mathrm{H}_{4}$ diterima, yang mengindikasikan bahwa brand imagedinilai mampu memediasi pengaruh kredibilitas celebrity endorser terhadap niat beli pada konsumen kosmetikMaybelline.Hasil penelitian ini didukung oleh penelitian sebelumnya yang dilakukan oleh Rini dan Astuti (2012), Ruslim dan Andrew (2012), Wahyuni dan Suparna (2014), serta Wang dan Tsai (2014) yang menyatakan bahwa brand image mampumemediasi pengaruh kredibilitas celebrity endorser terhadap niat beli.

\section{SIMPULAN}

Kredibilitas celebrity endorser berpengaruh positif dan signifikan terhadap brand image. Hasil penelitian menunjukanbahwa semakin pelanggan mengingat suatu merek terhadap melihat keahlian dan daya tarik celebrity endorser dalam penyapaian pesan maka akan meningkatkan brand image pada konsumen kosmetik Maybelline di Kota Denpasar. Brand image berpengaruh positif dan signifikan terhadap niat beli. Hasil penelitian menunjukan bahwa semakin pelanggan mengingat suatu merek maka akan semakin tinggi niat untuk membeli 
pada konsumen kosmetik Maybelline di Kota Denpasar.Kredibilitas celebrity endorser berpengaruh positif dan signifikan terhadap niat beli. Hasil penelitian menunjukan bahwa semakin tertarik pelanggan terhadap keahlian dari celebrity endorser maka akan semakin tinggi niat beli dari pelanggan pada kosmetik Maybelline di Kota Denpasar. Brand image memediasi pengaruh kredibilitas celebrity endorser terhadap niat beli. Hasil penelitian ini menunjukan bahwa kekuatan brand image dapat mempengaruhi dan mementukan pengaruh kredibilitas celebrity endorser terhadap niat beli pada konsumen kosmetik Maybelline di Kota Denpasar.

Tanggapan responden pada variabel kredibilitas celebrity endorser memperlihatkan indikator selebriti dapat dipercaya dalam menyampaikan informasimerupakan variabel yang memperoleh skor terendah, maka sebaiknya pihak produsen kosmetik Maybelline mampu memilih seorang endorser yang dapat menyampaikan iklan yang baik, sehingga akan meningkatkan minat calon konsumen untuk membeli produk kosmetik Maybelline.

Tanggapan responden pada variabel brand image memperlihatkan indikator citra produk kosmetik Maybelline yang dibintangi celebrity endorser bermanfaat dan cocok terhadap semua kulit merupakan variabel yang memperoleh skor terendah, maka sebaiknya pihak produsen Maybelline memilih celebrity yang sesuai terhadap produk yang di iklankan yang akan menonjolkan suatu merekdan citra dari produk kosmetik Maybelline sehingga akan terlihat produk kosmetik Maybelline bermanfaat dan cocok untuk semua jenis kulit. Tanggapan responden pada variabel niat beli memperlihatkan indikator sesegera ingin membeliproduk 
kosmetik Maybelline merupakan variabel yang memperoleh skor terendah, maka sebaiknya pihak produsen kosmetik Maybelline lebih memberikan inovasi yang lebih menarik sehingga konsumen akan penasaran terhadap produk kosmetik Maybelline yang akan menimbulkan niat beli dan meningkatkan upaya promosi.Bagi peneliti selanjutnya, diharapkan dapat menambah variabel yang berpengaruh terhadap brand image dan niat beli. Selain itu terhadap melibatkan responden yang lebih banyak akan meghasilkan data yang lebih akurat.

\section{REFERENSI}

Amanda, Putri. (2014). Peran Brand image dalam Memediasi Pengaruh Celebrity endorser terhadap Brand Equity Kartu Halo.Jurnal Ilmiah Mahasiswa Universitas Widyatama,8(2), 53-67.

Apejoye, Adeyanju. (2013). Influence of Celebrity Endorsement of Advertisement on Students' Purchase Intention. Mass Communication and Journalism, $3(3), 1-7$.

Arsinta,G.A.P. \& Purnami,N.M. (2015). Peran Persepsi Nilai Dalam Memediasi Pengaruh Kredibilitas Celebrity Endorser Pada Niat Beli Produk Kosmetik Maybelline di Kota Denpasar. Matrik: Jurnal Manajemen,Strategi Bisnis dan Kewirausahaan 9(2),123-124.

Chi, H.K. Yeh, \& M.W. Huang.(2009).The Influences Ebdorser,Brand image, Brand Equity, Price Promotion on Niat membeli: The Mediating Effect of Advertising Endorser. The Journal of Global Business Management, 5 (1),221-233.

Chung, Y.C., Kevin., Derdenger, T.P., \& Kannan.S. (2013). Economic value of celebrity endorsement: Tiger Woods' impact on sales of Nike Golf Balls. Marketing Science, 32(2),271-293.

Dei, Theoria Ayu Gusti \& I Gede Sukaatmadja.(2015).Peran Brand image Memediasi Pengaruh Kredibilitas Celebrity endorserterhadap Purchase Intention.E-jurnal Manajemen Universitas Udayana, 4(5),1206-1228.

Damanik, B. D, Kristiana E.,\& Retna.S.W.(2011).Persepsi Remaja Putri di Kota Ambon Tentang Resiko Terpapar Kosmetik Berbahaya dan Perilakunya dalam Memilih dan Menggunakan Kosmetik.Berita Kedokteran Mayarakat, 6(1),1-9.

Damanik Belinda Tiffany.(2015).Pengaruh Celebrity endorserterhadap Niat Beli Kosmetik Wardah. Skripsi Sarjana Administrasi Bisnis Universitas Telkom Universitas Telkom, 8(1),58-68. 
Durianto, Darmadi. (2001). strategi menaklukan pasar melalui Riset Ekuitas dan Perilaku. Jakarta : PT Gramedia Pustaka Utama.

Ferdinand, Augusty. (2002). Structural Equation Modeling dalam Penelitian Manajemen. Semarang: Badan Penerbit Universitas Diponegoro.

Ghozali, Imam. (2013). Aplikasi Analisis Multivariate terhadap Program IBM S PSS 21 Update PLS Regresi. Semarang: Universitas Diponegoro.

Hansudoh, Steven Agustisnus. (2012). Pengaruh Celebrity Endorsement terhadap Purchase Intention Melalui Perceived Value Pada Produk Top Coffe di Surabaya. E-Journal Universitas Katolik Widya Mandala Surabaya, 1 (05), $1-7$.

Hamdiana. (2005). Strategi Pemasaran. Jakarta: PT Gramedia Pustala Mizan Pustaka.

Haryantana,Handre Gede I Putu. (2015). Pengaruh Celebrity endorser,Brand image dan Persepsi Kualitas Terhadap Niat Beli Sepeda Motor Honda Scoopy di Kota Denpasar. E- Jurnal Manajemen Unud, 4(9),2806-2830.

Hollensen, Svend, \&Christian Schimmelpfennig. (2013).Selection of Celebrity endorsers: A Case Approach to Developing an Endorser Selection Process Model.Marketing Intelligence \& Planning, 31(1),88-102.

Indraswari, M., Mahadewi, N.M., \& Pramudana, K.A.S. (2014).Pengaruh kredibilitas celebrity endorser dan kewajaran harga terhadap niat beli konsumen wanita pada Online Shop produk pakaian.E-Jurnal Manajemen Universitas Udayana,3 (4),938-955.

Indonesia Finance Today. Berita Industri: Indonesia Lahan Subur Industri Kosmetik. Kemenperin.go.id/artikel/5897. Diakses tanggal 11 Desember 2014.

Jalilvand, Mohammad Reza, Neda Samiei. (2012). The Effect of Electronic Word of Mouth on Brand image and Purchase Intention. Marketing Intelligence \& Planning,30 (4),460-476.

Kurniawan, Saverius Dwi. (2012). Analisis Pengaruh Brand Loyalty, Brand image, Iklan dan Percieved Quality Terhadap Niat Beli Konsumen XL Prabayar di Kota Surabaya. Jurnal Universitas Katolik Widya Mandala Surabaya, 1 (1),1-5.

Khan, Bilal M. (2013). The Effect of Indian Celebrity Credibility Dimensions on Purchase Intention of Indian Consumers. Published in Prague Conference, IISES and University of Economics Prague.

Kotler, P., \& Keller, K.L. (2009). Manajemen Pemasaran Jilid 1, Edisi Ketiga Belas. Jakarta: Erlangga.

Kim, Jaeil., Wonghee Han, Dongtae Kim \&Widya Paramitha.(2013). Is Beauty in the Eye of the Beholder.Gender and Beauty in the Cosmetics Sector. Emerald Insight, Marketing Intelligence \& Planning,31(2). 
Kiswalini, A.,\& Nurcahya, I.K. (2014). Pengaruh celebrity endorser, brand image, dan kepercayaan konsumen terhadap keputusan pembelian sepeda motor Honda Vario di Kota Denpasar.E-Jurnal Manajemen Universitas Udayana, 3(6),1522-1534.

Malhotra, Naresh K. (2004). Riset Pemasaran: Pendekatan Terapan, Jilid I. Jakarta: Indeks.

Nisa, Lathifatun Hanif \&Nora Nailul Amal. (2013). Celebrity endorser dan Brand image (Studi Kuantitatif Eksplanasi Pengaruh Sule Sebagai Celebrity endorser Dalam Iklan Televisi terhadap Pembentukan Brand image Kartu AS Telkomsel Di Kalangan Mahsiswa Komunikasi FISIP UNS Angkatan 2011/2012).Jurnal Ilmiah Ilmu Komunikasi Fakultas Ilmu Sosial dan Ilmu Politik,1-17.

Pakaya, Salman.(2013).Pengaruh celebrity endorser pada iklan Fresh Care terhadap minat beli konsumen.Fakultas Ekonomi dan Bisnis Universitas Negeri Gorontalo. 4(2),18-52.

Peter, J Paul \& Jerry C Olson. (2013).Perilaku Konsumen dan Strategi Pemasaran Terjemahan oleh Diah Tantri Dwiandani Edisi Kesembilan Jilid 1. Jakarta: Erlangga.

Pradhan Debasis, Israel Duraipadian., \& Dhruv Sethi. (2014). Celebrity Endorsement: How Celebrity- Brand - User Personality Congruence Affects Brand Attitude And Purchase Intention. Jurnal of Marketing Communications, 2(2), 1-18.

Prayuana, Helena Hermawati, Anik Lestari Andjarwati. (2013).Pengaruh Penggunaan Celebrity endorser Irfan Bachdim dan Event Sponshorship terhadap Citra Merek Minuman Isotonik Pocari Sweat. Jurnal Ilmu Manajemen,1(1),15-25.

Putra, I M.S.M \& Giantari, I. G.A.K. (2014).Pengaruh brand image, celebrity endorser, kualitas produk, dan kewajaran harga terhadap niat membeli Sepeda Motor Matic Merek Hondadi Kota Denpasar.E-Jurnal Manajemen Universitas Udayana, 3 (10),2869-2886.

Putra, Triya Darma I.K \& Eka Sulistyawati, (2015).Peran Brand image dalam Memediasi Pengaruh Celebrity endorser terhadap Niat Beli.E-Jurnal Manajemen Universitas Udayana. 4(6),1722-1734.

Rahyuda, I Ketut, (2017).Metodelogi Penelitian.Fakultas Ekonomi dan Bisnis Universitas Udayana.

Riduwan dan Engkos Achmad Kuncoro. (2011).Cara Menggunakan dan Memaknai Analisis Jalur (Path Analysis). Bandung: Alfabeta.

Rini, Endang Sulistya \& Dina Widya Astuti. (2012). Pengaruh Agnes Monica Sebagai Celebrity endorserTerhadap Pembentukan Brand image Honda Vario.Jurnal Bisnis dan Manajemen, 6 (6),1-12. 
Rizky, F.S. \& Wahyuati, A. (2016).PengaruhCelebrity endorser dan Brand image terhadap Keputusan Pembelian Melalui Minat Beli. E-Jurnal Sekolah tinggi Ilmu Ekonomi Indonesia (STIESIA) Surabaya, 5(5), 2461-0593.

Rodriguez, Karina P. (2008). Apprael Brand Endorsers and Their Effects on Purchase Intentions: A Study of Philippine consumers. Phillppine Management Review, (15),83-99.

Roy, S., V. Jain, \& P. Rana. (2013). The Moderating Role of Consumer Personality and Source Credibility in Celebrity Endorsements. AsiaPacific Journal of Business Administration, 5(1),72-88.

Ruslim, Tommy Setiawan \& Richard Andrew. (2012). Pengaruh Brand image dan Product Knowledge Terhadap Purchase Intention (Kasus: Kosmetik Merek "X”). Media Bisnis Universitas Tarumanegara,4 (1),34-44.

Sallam, Methaq Ahmed Abdulmajid. (2011). The Impact of Source Credibility on Saudi Consumer's Attitude Toward Print Advertisement: The Moderating Role of Brand Familiarity. International Jurnal of Marketing Studies, 3 (4),63-77.

Sabunwala, Z. (2013). Impact of Celebrity Brand Endorsements on Citra merekand Product Purchase - A Study for Pune Region of India.International Jurnal of Research in Business Management.1(6),3742.

Sari, Dinny Puspita \& Edin S. Djatikusuma. (2013). Pengaruh Celebrity endorser Ayu Ting Ting Dalam Iklan Televisi Terhadap Brand image Produk Mie Sarimi. STIE MDP,5(2),1-9.

Sekaran, Uma.(2006). Metodologi Penelitian untuk Bisnis. Terjemahan oleh Kwan Men Yon.Edisi 4.Buku 1. Jakarta: Salemba Empat

Sertoglu, A.E., Catli, O., \& Korkmaz, S. (2014). Examining the effect of endorser credibility on the consumers' buying intentions: an empirical study in Turkey.International Review of Management and Marketing,4 (1),66-77

Shafiq, R., Raza, I., Rehman, M. Z. (2011). Analysis of The Factors Affecting Customers' Purchase Intention: The Mediating Role of Percieved Value. African Jurnal of Business Management, 5 (26),10577-10585

Schiffman, Leon G. \& Leslie Lazar Kanuk. (2008). Perilaku Konsumen, Edisi Ketujuh. Jakarta: PT Indeks.

Shimp, Terence A. (2014). Komunikasi Pemasaran Terpadu dalam Periklanan dan Promosi Edisi 8. Jakarta : Selemba Empat.

Stephanie, Elizabeth., \& Leonid Julihan Rumambi. (2013). Analisa Pengaruh Rio Dewanto Dan Donita Sebagai Celebrity endorserterhadap Minat Beli Produk Axe Anarchy Terhadap Daya Tarik Iklan Dan Efek Iklan Sebagai Variabel Intervening. Jurnal Manajemen Pemasaran, 1(2),1-9. 
Silvera, D.H., \& Benedikte, A. (2004). Factorspredicting the effectiveness of celebrity endorsemen tadvertisements. University of Tromso, Tromso,Norway,European Journal of Marketing, 38(11/12), 1509-1526.

Sugiyono. (2016). Metode Penelitian Bisnis: Pendekatan Kualitatif dan Kuantitatif dan R\&D. Bandung: Alfabeta.

Suryani, Tatik. (2008). Perilaku Konsumen; Implikasi pada Strategi Pemasaran. Yogyakarta: Graha Ilmu.

Tanomi, Romy Victor. (2012). Pengaruh Iklan Terhadap Niat Beli Konsumen Melalui Citra Merek dan Sikap Pada Minuman Isotonik Mizone di Surabaya. Jurnal Ilmiah Mahasiswa Manajemen Universitas Widya Mandala, 1 (6),1-7.

Tobing, M.L. Renaldo. (2013). Pengaruh Penggunaan Iwan Fals Sebagai Celebrity endorser dalam Iklan terhadapBrand image TOP Coffee. Jurnal. Universitas Brawijaya. 2(1),1-15

Van der Waldt, D., M. Van Loggerenberg \& L. Wehmeyer. (2009). Celebrity Endorsements Versus Created Spokespersons in Advertising: A Survey Among Students. SAJEMS, 12(1),110-114.

Wahyuni, Ni Luh Gede \& Gede Suparna. (2014). Pengaruh Brand image dan Product Knowledge terhadap Purchase Intention Produk Tas Tiruan Di Kota Denpasar. E-Journal Universitas Udayana, 3 (4),1022-1034.

Wang, Ya-Hui., Cing-Fen Tsai. (2014). The Relationship BetweenBrand image and Purchase Intention: Evidence From Award Winning Mutual Funds. The International Jurnal of Business and Finance Research, 8 (2),27-40.

Wijanarko,Puthud. Suharyono \& ZainuArifin. (2016). Pegaruh celebrity endorser terhadap citra merek dan dampaknya pada keputusan pembelian (Survei kepada Pengunjung Warung Kopi Kriwul, Kelurahan Merjosari, Kecamatan Lowokwaru, Kota Malang yang Pernah Melihat Iklan dan Membeli TOP Coffee). Jurnal Administrasi Bisnis. 34 (1),165-171.

Weli, I Made \& I Ketut Rahyuda, (2016). Peran brand image dalam memediasi country of origin terhadap purchase intention. E-Jurnal Manajemen Universitas Udayana, 5(3),1690-1716.

Zafar, Q., \& Rafique, M. (2012). Impact of Celebrity Advertisement on Customers' Brand Perception and Purchase Intention.Jurnal of Business and Management Sciences, 1 (11),53-67. 